\title{
ENVIRONMENTAL POLLUTION RESULTING FROM OLIVE OIL PRODUCTION IN PALESTINE
}

\author{
Awni Khatib, Fathi Aqra* and Nader Yaghi \\ Department of Chemistry, \\ Faculty of Science and Technology, \\ Hebron University, P.O. Box 40, \\ Hebron, West Bank, PALESTINE \\ Sobhi, Basheer and Isam Sabbah \\ Research and Development Center, \\ The Galilee Society, P. O. Box 437 \\ Shefa-Amr, 20200 ISRAEL \\ Basam Al-Hayek and Mohammed Mosa \\ Royal Scientific Society, \\ P.O. Box 1438, Al-Jubaiha 11941, \\ Amman, JORDAN
}

\begin{abstract}
The level of environmental impact of olive oil production in Palestine was evaluated by measuring the parameters: $p H$, chemical oxygen demand (COD), biochemical oxygen demand (BOD), total suspended solids (TSS), total dissolved solids (TDS), concentration of fat, oil, and grease (FOG), phenols, electric conductivity (EC) total phosphorus (T-P) and total Kjeldahl nitrogen (TKN, and compared with the Jordanian standard values. The results show that the value of these parameters are too high. A local survey has also been conducted by designing a questionnaire that covers oil production yield, water consumptions in olive washing and in oil recovery, wastewater generation relative to olive processed and oil generated, and solid waste product. The data were collected from 92 local olive oil mills, which were analyzed and organized according to the investigated parameters, and categorized according to local selected areas in the West Bank such as Hebron (South), Nablus (Center) and Jenine (North).
\end{abstract}

*Author to whom all correspondence should be directed, e-mail: fathiaqra2009@hotmail.com 
The results revealed local variations in oil yield and solid waste product due to variations in the type of olive produced. The olives from the South ware found to contain larger solid content than those from the North, resulting in lower oil yield. The overall results indicated that the average oil yield was $23.7 \%$, the solid waste product was $40,0 \%$ while the remaining balance was the water content (36.7\%) in the olive fruit. A representative value at $1.7 \mathrm{~m}^{3} /$ ton for wastewater generation was found to be high compared to similar values in other places of the world. This requires a criterious review of the technology and operation of olive mills in Palestine. The characteristics of $O M W$ were found to violate the standards for $O M W$ and this requires the attention of authorities.

\section{KEY WORDS: Olives, Olive oil, Oil yield, Solid waste, Water Consumption, Wastewater, COD, BOD, TDS, TSS, OMW}

\section{RESUMO:}

O impacto da produção de óleo de oliveira na Palestina foi avaliado medindo parâmetros tais como pH, demanda química de oxigênio (DQO), demanda bioquímica de oxigênio (DBO, total de sólidos em suspensão (TSS), total de sólidos dissolvidos (TSD), concentração de óleo e gorduras, fenóis, condutividade elétrica, total de fósforo; total de nitrogênio (Kjeldahl) e comparando com valores padrão do Reino da Jordânia. Os dados experimentais foram coletados em 92 locais diferentes nas regiões de Hebron (Sul), Nablus (Centro) e Jenine (Norte). Os resultados experimentais mostraram um rendimento médio de azeite de $23,7 \%$ e dejetos sólidos de 40,0\%. O conteúdo de água das azeitonas foi de $36,7 \%$. O valor de $1,7 \mathrm{~m}^{3}$ ton de água residual pode ser considerado alto quando comparado com outros lugares do mundo e sugere uma avaliação da tecnologia usada na produção do azeite de oliva.

PALAVRAS-CHAVE: Azeitonas, Azeite de oliveira, Rendimento de azeite, Dejetos sólidos, Consumo de água, DQO, DBO, TSS, TSD.

\section{INTRODUCTION}

Olive oil extraction is one of the most traditional food industries in the Mediterranean region. In addition to olive oil, this industry produces by-products, in particular olive mill wastewaters (OMWs) and olive husks, which represent a serious environmental problem. Olive mill effluents constitute a serious environmental problem in the Mediterranean sea region due to the unique features associated with this type of agro-waste (i.e. seasonal and localized production, high and diverse organic load, low flow rates). Therefore, it is not surprising that research efforts have been directed towards the development of efficient treatment technologies including various physico-chemical and biological processes. Annually, approximately $1.8 \times 10^{6}$ tons of olive oil is produced worldwide, with a majority being produced in the Mediterranean basin (1-3). Treatability of olive mill wastewater has been investigated using respirometric method (4) and other methods (5-11). Olive oil 
industries were considered responsible for a great amount of pollution and there has been a strong need for optimization of olive oil waste treatment systems. Study of the inhibitory activity of phenolic compounds found in olive products has been investigated (12). Olive mill sludge (OMS), a by-product resulting from natural evaporation of olive oil processing effluent, poses a major environmental threat (13). In Palestine, olive and olive oil production is an important source of income for a considerable sector of farmers. From an agricultural prospective, olives and their oil have a major contribution in the Palestinian economy. Olive farms cover almost half of the cultivated area in The West Bank, and oil production contributes about $28.7 \%$ of the agriculture domestic income. There are about 246 olive mills in the West Bank (14). The operations of these mills are split between modern and traditional models. Naturally, olive mills are generally situated close to olive orchards. The Palestinian Nation Information Center published the overall statistical information about the number of mills, and total amounts of olive and olive oil produced in The West Bank and Gaza between the years 1998 to 2002 . There is a slight change in the overall percentage oil yield from year to year. Generally extraction of oil is carried out either by continuous or discontinuous processes, and both methods generate wastewater, which consists of the water contained in olive fruit, the added water required for washing the fruit, and for the centrifugation process. With the continuous process, the average amount of olive mill wastewater (OMW) is 1.2-1.8 $\mathrm{m}^{3} /$ ton of olives, while with the discontinuous process; it is only $0.4-0.5 \mathrm{~m}^{3} /$ ton of olives (15).

The color of the wastewater produced by both methods is usually black or reddish black due to the presence of phenolic compounds. The typical composition of OMW includes water $(83 \%)$, organic compounds $(15 \%)$, and inorganic chemicals (about $2 \%$ ). The organic load in OMW is considered one of the highest of all concentrated effluents, being 100-150 times higher than the organic load of domestic wastewater. In general, OMW produced in discontinuous mills contains higher organic load than those generated in continuous mills. OMW is acidic, and contains a high concentration of total dissolved solids (TDS), total suspended solids (TSS), phenols, and other organic matter. The organic content is characterized by high levels of chemical oxygen demand (COD), biochemical oxygen demand (BOD), and very high concentration of fat, oil, and grease (FOG) (Jordanian Ministry of Agriculture 1998). No standard for OMW discharge disposal is currently imposed in Palestine, but the Jordanian standards are adopted (Table 1) (16-18). The BOD and COD maximum concentrations in OMW reach 100,000 and $220,000 \mathrm{mg} / \mathrm{L}$, respectively. The OMW consist of toxic and non-toxic organic materials such as sugars, tannins, polyphenols, polyalcohols, pectins, proteins, and lipids. Ecological stabilization and detoxification of their effects are expensive and ineffective (19-20).

Currently, there is no appropriate method applied for treating OMW in Palestine; it is usually disposed of in sewage systems and/or cesspools in addition to being discharged into water streams and valleys of the region. Due to the presence of a high load of toxic organic compounds, the improper discharge of OMW causes the disruption of biological activities in domestic wastewater ponds. This creates a strong and unpleasant odor due to aerobic digestion in open air systems, and poses a threat to surface and groundwater (21). The disposal of OMW causes serious environmental problems during the olive harvest season. Also, a large amount of solid waste is generated with wastewater. 
Table 1. Characteristics of OMW in Jordan and comparison with Jordanian standards and regulations for $O M W$.

\begin{tabular}{|c|c|c|c|c|c|}
\hline \multirow[b]{2}{*}{ Parameter } & \multirow[b]{2}{*}{ Unit } & \multirow{2}{*}{$\begin{array}{c}\text { OMW } \\
\text { Characteristics } \\
\text { Min.-Max. }\end{array}$} & \multicolumn{3}{|c|}{ Maximum Allowable Limit- Jordanian Standards } \\
\hline & & & $\begin{array}{c}\text { Disposal to wadis } \\
\text { and rivers }\end{array}$ & $\begin{array}{l}\text { Reuse for } \\
\text { irrigation }\end{array}$ & $\begin{array}{c}\text { Discharge to } \\
\text { sanitary systems }\end{array}$ \\
\hline $\mathrm{pH}$ & SU & $5.48-5.91$ & $6.8-9.0$ & $6.5-8.4$ & $5.5-9.5$ \\
\hline COD & $\mathbf{m g} / \mathbf{L}$ & $78536-160096$ & 150 & undetermined & 2100 \\
\hline $\mathrm{BOD}_{5}$ & $\mathrm{mg} / \mathrm{L}$ & $23248-63271$ & 50 & undetermined & 800 \\
\hline TSS & $\mathrm{mg} / \mathrm{L}$ & $14207-46188$ & 50 & 100 & 1100 \\
\hline TDS & $\mathrm{mg} / \mathrm{L}$ & $16984-80355$ & 3000 & 2000 & \\
\hline FOG & $\mathbf{m g} / \mathrm{L}$ & $2008-13118$ & 5 & 5 & 50 \\
\hline Phenol & $\mathrm{mg} / \mathrm{L}$ & $1739-4432$ & 0.002 & 0.002 & 10 \\
\hline
\end{tabular}

This emphasizes the environmental pollution associated with olive oil production and highlights the need for this study. In continuation to our earlier studies (22-23), this article describes the water consumption and water extracted during olive oil extraction processes, as well as the physical-chemical analysis of the wastewater from this agribusiness industry. It evaluates the level of environmental impact of olive oil production in Palestine through two routes; first by measuring the parameters PH, COD, BOD, TDS, TSS and TKN of 61 samples from different areas and secondly by conducting a survey covering 92 olive mills in the West Bank.

\section{EXPERIMENTAL}

Ninety two olive mills through out The West Bank could be reached and included in the survey. A questionnaire was prepared and the obtained data were analyzed and organized according to the oil yield and solid waste product, and then categorized with respect to local areas in the West Bank; Hebron (south), Nablus (middle) and Jenine (North). Experimental work was performed for determining typical characteristics of OMW in Palestine, by analyzing samples from 61 olive mills from North, Middle and South Palestine during three intervals of the harvest season (beginning, middle and end of season). The methods used to obtained the physical chemical data of the wastewater and the major characteristic methods and analysis of the parameters $\mathrm{pH}, \mathrm{COD}, \mathrm{BOD}, \mathrm{TSS}, \mathrm{TDS}, \mathrm{FOG}, \mathrm{TKN}$, phenols, electric conductivity $(\mathrm{EC})$ and total Phosphorus $(\mathrm{T}-\mathrm{P})$ of the wastewater were determined using the standard tests (24). 


\section{RESULTS AND DISCUSSION}

Analysis of the overall data published by the Palestinian National Information Center (PNIC) [14] provides (Fig 1) oil yield (defined as percentage of amount of oil produced per amount of olive processed), which compares the amount of olives and olive oil produced in various parts of the West Bank and the overall yield in 2002. The largest amounts of olives and olive oil were produced in Jenine. There are some variations in the overall yield between the locations. The estimated average overall yield was $22.3 \%$. Obviously, olives and olive oil production is more popular in the North areas, and the oil yield is higher than that in the South. The obtained fitting $\mathrm{R}^{2}$ values are above 0.99 . The oil yield (\%Oil/Olive) has an average value of $23.7 \%$, which is in accordance with the previous reports [5-7], with a difference of $1.4 \%$. Both the linearity of the data and the closeness of the obtained yield to that estimated previously confirm the validity of the survey conducted. This emphasizes the fact that the oil yield in Hebron (South) is lower than that in the Middle or North (Jenine and Nablus). Similar to oil yield data, the obtained fitting $\mathrm{R}^{2}$ values are high (almost above 0.99 ) confirming linearity. The fraction of solid waste (quantity of solid waste produced per quantity of processed olives) has an average value of $40,0 \%$. Relatively, olive mills in Hebron area produced a larger fraction of solid waste compared to those in the North areas.

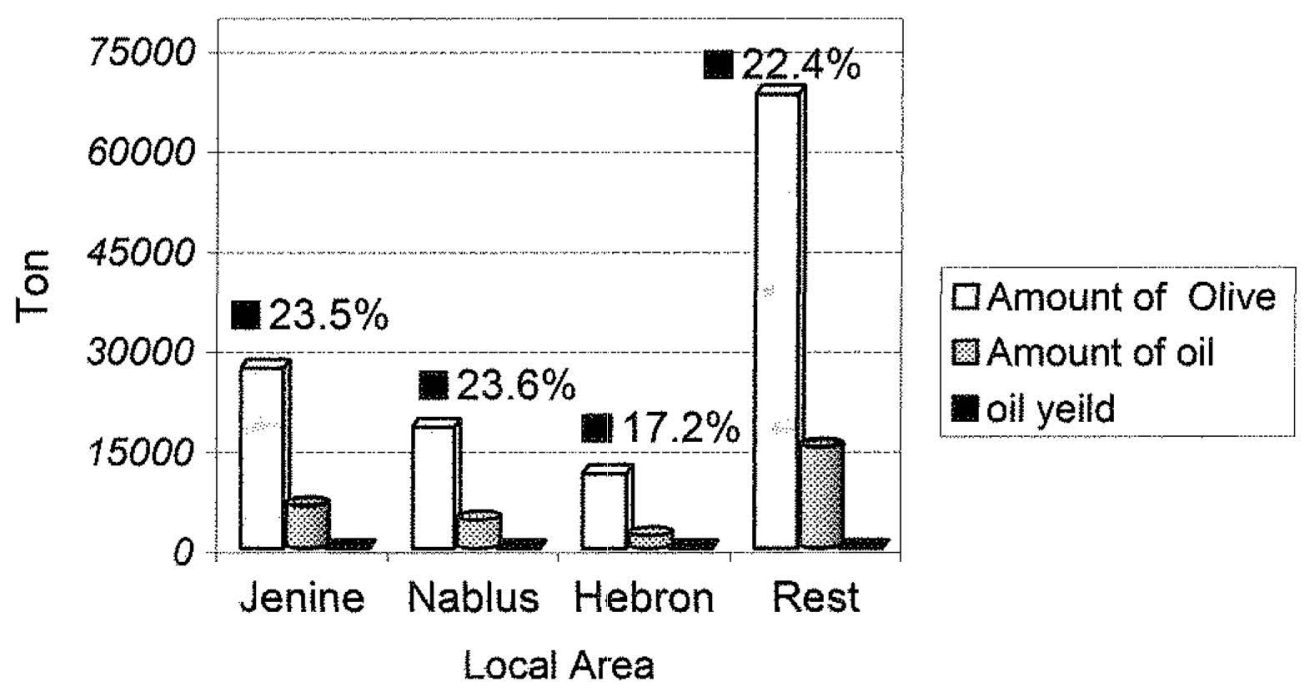

Figure 1.Comparison of the amount of olives and olive oil produced in various parts of The West Bank and Gaza and the overall oil yield in the year 2002

In olive mills, wastewater is generated from various sources including water coming from olives and water used for processing (water consumption). The latest source comes from two different steps; washing of olives and extraction of oil. The designed questionnaire enabled us 
to gather data for total wastewater, water used for washing and water used in extraction. The summation of water used for washing and extraction provided data for water consumption, while the difference between total wastewater and water consumption provided data for water coming from fruit. The results obtained for the various forms of water are plotted against quantity of processed olives and presented in Figs. 2, 3 and 4. Figure 2 represents the data for water coming from olive fruit versus quantity of processed olives, in Hebron, Nablus and Jenine. Obviously, the general trend is linear, the slope of which provides a representative value of the fraction of water content in the olive fruits. Table 2 provides the results of linear curve fitting for these data. Similar to both oil yield and solid fraction, the obtained fitting $\mathrm{R}^{2}$ values are all above 0.99 . Relatively, olives in Hebron area contain a slightly larger fraction of water than those in the North areas. In general, the fraction of water content in olive (quantity of water from olive fruit per quantity of processed olives) has an average value of nearly $40 \%$.

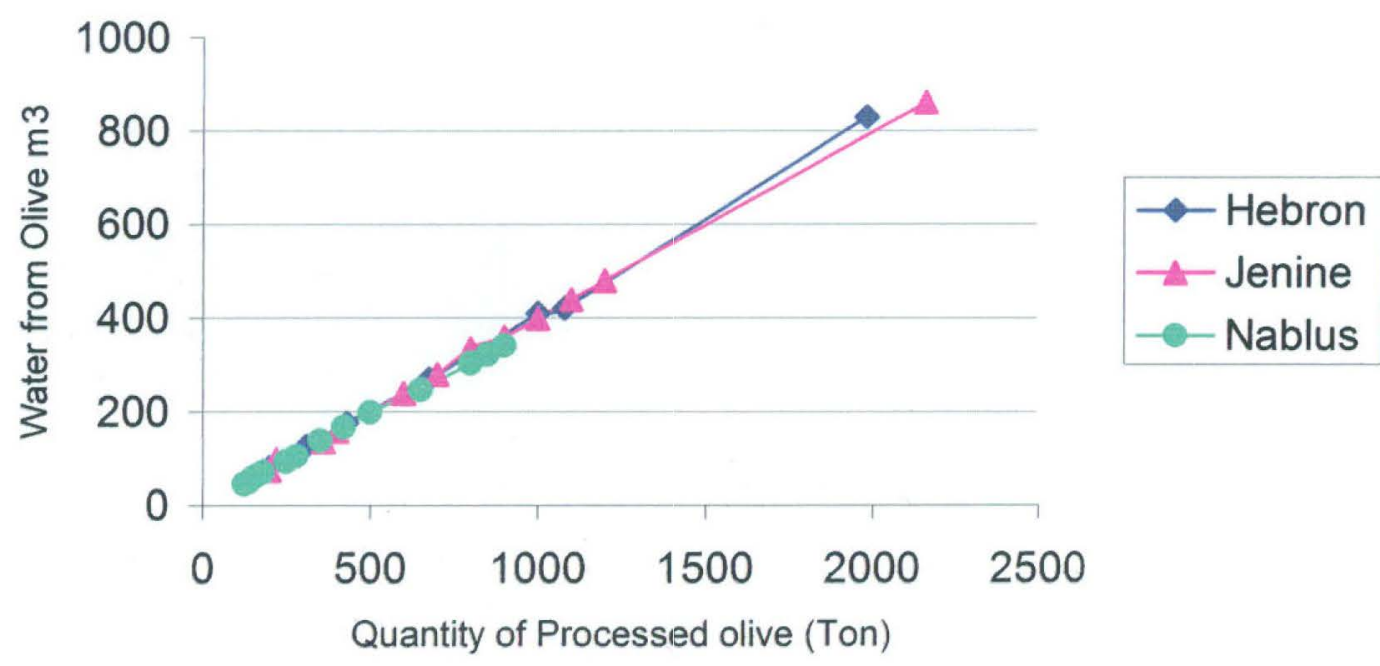

Figure 2.Quantity of water coming from olive fruit versus quantity of processed olives for data from Hebron (triangles), Nablus (circles) and Jenine (diamonds) 
SOUTH. BRAZ. J. CHEM., Vol. 17, No. 17, 2009

A. Khatib, F. Aqgra, N. Yaghi, S. Basheer, I. Sabbah, B. Al-Hayek and M. Mosa

Table 2. Results of linear curve fitting for data of water from olive fruit obtained from the conducted survey.

\begin{tabular}{|c|c|c|c|}
\hline Local Area & Fitting Line & $\begin{array}{c}\text { Fitting } \\
\mathbf{R}^{2}\end{array}$ & $\begin{array}{l}\text { Fraction of Water } \\
\text { coming from olive } \\
\text { fruits }\end{array}$ \\
\hline Hebron & $Y=0.411 X$ & 0.9983 & 0.411 \\
\hline Nablus & $Y=0.382 X$ & 0.9991 & 0.382 \\
\hline Jenine & $Y=0.401 X$ & 0.9992 & 0.401 \\
\hline $\begin{array}{l}\text { All data as one plot } \\
\text { (Average) }\end{array}$ & $Y=0.398 X$ & 0.9988 & 0.398 \\
\hline
\end{tabular}

Table 3 summarizes the obtained characteristics of olives. From mass balance, the weight of the oil yield, the solid waste and the water content should be equal to the mass of the olive fruit used, that is the ratio must be unity. With the obtained average values, the sum is greater than unity (1.038) with a percentage error of $3.8 \%$. Thus, these average values provide representative values for olives characteristic in Palestine with reasonable accuracy. Figure 3 represents water consumption (for washing and extraction of oil) versus quantity of processed olive. Similar to other parameters, the tend is linear. Using linear curve fitting for these data provides fitting values $\left(\mathrm{R}^{2}\right)$ all above 0.99 as listed in Table 4 . The slope represents the average value of water consumption per ton of processed olives. The average value is 1.193 $\mathrm{m}^{3} /$ ton. This value is relatively high, and it is of special concern in Palestine where water resources are very limited. Water consumption shall be minimized not only to reduce the generated wastewater, but also to reduce fresh water demand. This would require a technical review for operation of olive mills. 
SOUTH. BRAZ. J. CHEM., Vol. 17, No. 17, 2009

Olive Oil Production in Palestine

14

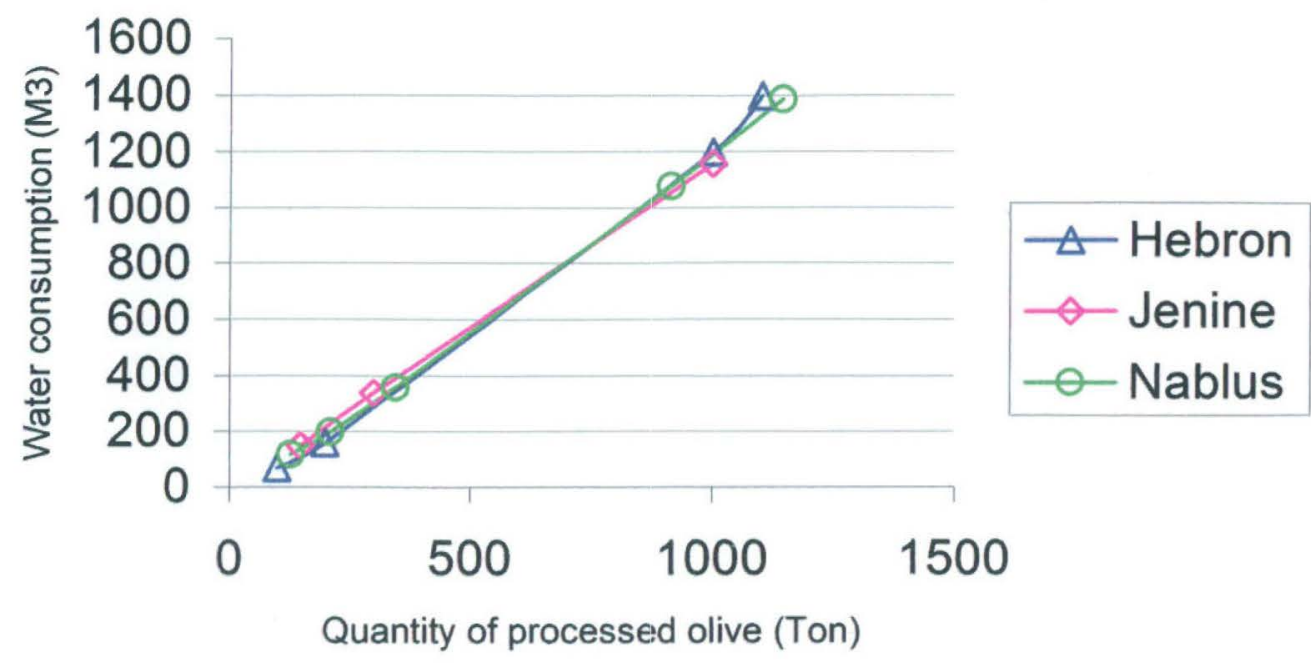

Figure 3.Quantity of consumption water versus quantity of processed olives for data from Hebron (triangles), Nablus (circles) and Jenine (diamonds)

Table 3. Summary of typical olive characteristics in Palestine.

\begin{tabular}{|c|c|c|c|c|}
\hline Local area & $\begin{array}{c}\text { Fraction of } \\
\text { oil* }\end{array}$ & Fraction of sollid* & Fraction of water* & Total* $^{*}$ \\
\hline Hebron & 0.219 & 0.429 & 0.414 & 1.062 \\
\hline Nablus & 0.248 & 0.399 & 0.382 & 1.029 \\
\hline Jenine & 0.243 & 0.379 & 0.401 & 1.023 \\
\hline Average & 0.237 & 0.403 & 0.398 & 1.038 \\
\hline
\end{tabular}

$* 1 \mathrm{Kg}$ 
SOUTH. BRAZ. J. CHEM., Vol. 17, No. 17, 2009

A. Khatib, F. Aqra, N. Yaghi, S. Basheer, I. Sabbah, B. Al-Hayek and M. Mosa

Table 4. Results of linear curve fitting for water consumption data.

\begin{tabular}{|c|c|c|c|}
\hline Local Area & Fitting Line & Fitting & Fraction of \\
& & $\mathbf{R}^{2}$ & consumption water \\
\hline Hebron & $\mathrm{Y}=1.230 \mathrm{X}$ & 0.9907 & 1.230 \\
\hline Nablus & $\mathrm{Y}=1.188 \mathrm{X}$ & 0.9945 & 1.188 \\
\hline Jenine & $\mathrm{Y}=1.155 \mathrm{X}$ & 0.999 & 1.155 \\
\hline All data as one plot & $\mathrm{Y}=1.191 \mathrm{X}$ & 0.9947 & 1.191 \\
\hline (Average) & & & \\
\hline
\end{tabular}

The average value is nearly $1.7 \mathrm{~m}^{3}$ wastewater/ton olives. This value is within the range of 1.2- $1.8 \mathrm{~m}^{3} /$ ton published in the literature as the range of OMW for continuous processes. For discontinuous processes, the range is $0.4-0.5 \mathrm{~m}^{3} /$ ton. In Palestine, the operations are split between continuous and discontinuous processes. However, the average value of the volume of OMW in Palestine fits within the range for continuous processes (which generates almost three time more wastewater than discontinuous processes). It is also more close to the maximum limit of that range. Consequently, it is important to perform a technical review for the implemented technology and procedures followed in Palestinian olive mill to reduce the rate of wastewater generation. Table 5 summarizes the results for water consumption and wastewater. In Hebron area, although the levels of production of olives and olive oil are lower than those in the north, both water consumption levels and the total wastewater levels are higher. This indicates that the environmental concerns in Hebron are still considerable. Figure 4 indicates that washing water in Hebron is comparable to that in north area. Thus, the rise in the total wastewater in Hebron comes from the high relative water content and high level of water used for extraction. Figure 5 presents plots of the total wastewater versus quantity of produced oil. Obviously, the curve for Hebron is above the other two curves for Jenine and Nablus. In addition to the previous reasoning regarding wastewater, the oil yield is lower, which contributes in raising this curve above the others. 
Table 5. Summary of results of wastewater from olive mills.

\begin{tabular}{|c|c|c|c|}
\hline Local Area & $\begin{array}{c}\text { Water } \\
\text { Consumption }\end{array}$ & $\begin{array}{c}\text { Water coming } \\
\text { from olive }\end{array}$ & wastewater $^{(*)}$ \\
\hline Hebron & 1.230 & 0.411 & 1.641 \\
\hline Nablus & 1.188 & 0.382 & 1.570 \\
\hline Jenine & 1.155 & 0.401 & 1.556 \\
\hline All data as one plot & 1.191 & 0.398 & 1.589 \\
\hline (Average) $^{\mathbf{m}^{3} \text { water / ton olives }}$ & & & \\
\hline
\end{tabular}

The results of the experimental work for the obtained typical characteristics of olive mills wastewater are illustrated in Table 6 . The values obtained at three intervals (beginning, middle and end of the harvest season) are listed and compared to the Jordanian standards for OMW for discharge to sanitary systems. The results indicate that there are some variations from time to time during the season However; the investigation of these variations requires a more extensive analysis and larger amount of data. The average values for the investigated characteristic parameters such as COD, TDS, TSS, BOD, FOG, TKN and phenols are too high and are all above the permitted values and thus the discharge of such OMW violates these standards and should receive sufficient attention from authorities to encounter the environmental problem. Comparison of the data obtained (Table 6) for the investigated parameters of pollution with previously reported data (Table 1) indicates that the chosen olive mills generate wastewater with characteristics within the range of the OMW in Jordan. 
SOUTH. BRAZ. J. CHEM., Vol. 17, No. 17, 2009

A. Khatib, F. Aqra, N. Yaghi, S. Basheer, I. Sabbah, B. Al-Hayek and M. Mosa

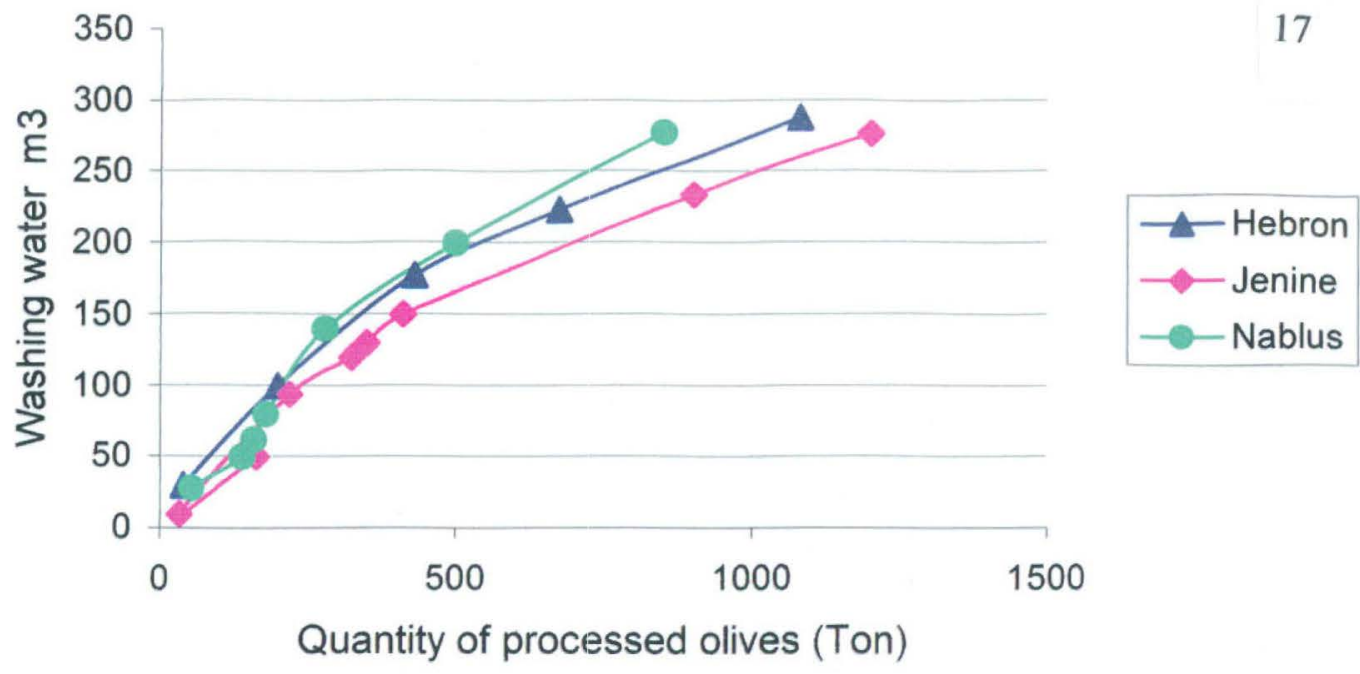

Figure 4.Quantity of washing water versus quantity of processed olive for data from Hebron (triangles), Nablus (circles) and Jenine (diamonds)

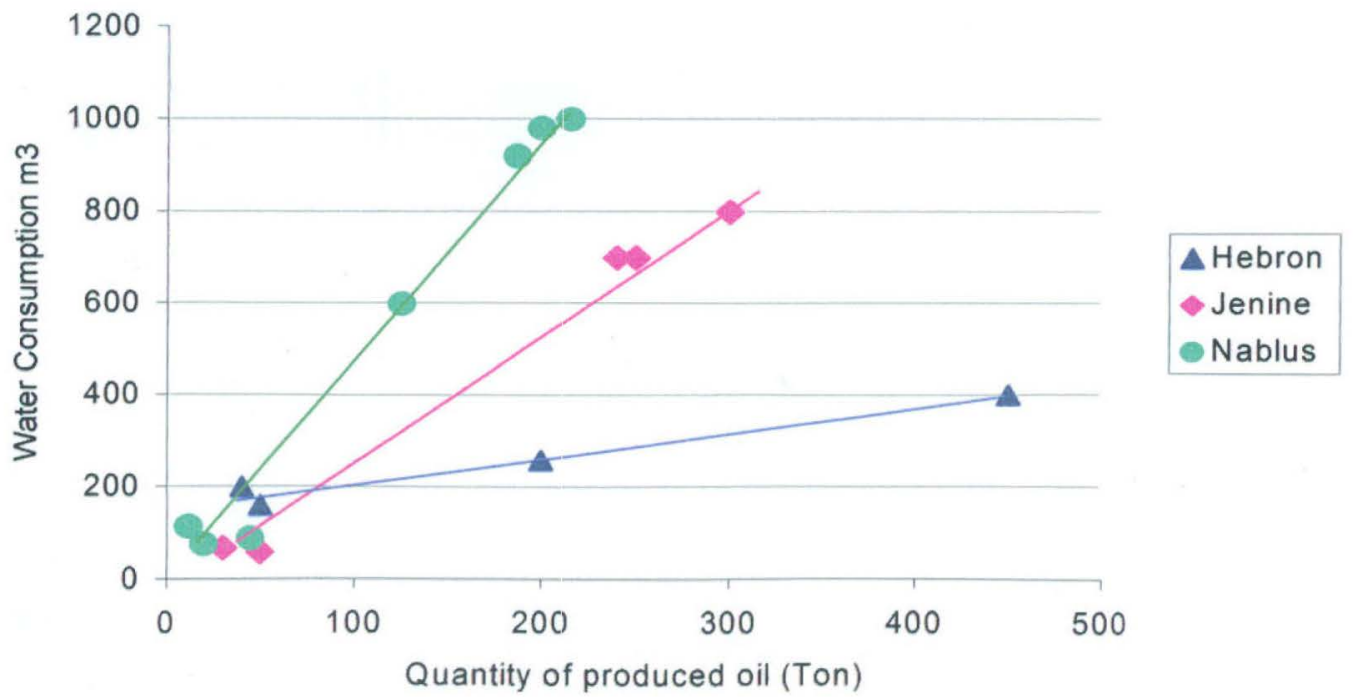

Figure 5.Quantity of total wastewater versus quantity of produced oil for data from Hebron (triangles), Nablus (circles) and Jenine (diamonds) 
SOUTH. BRAZ. J. CHEM., Vol. 17, No. 17, 2009

Olive Oil Production in Palestine

18

Table 6. Experimental results of OMW characteristics for sample obtained at the beginning, middle and end of harvest season.

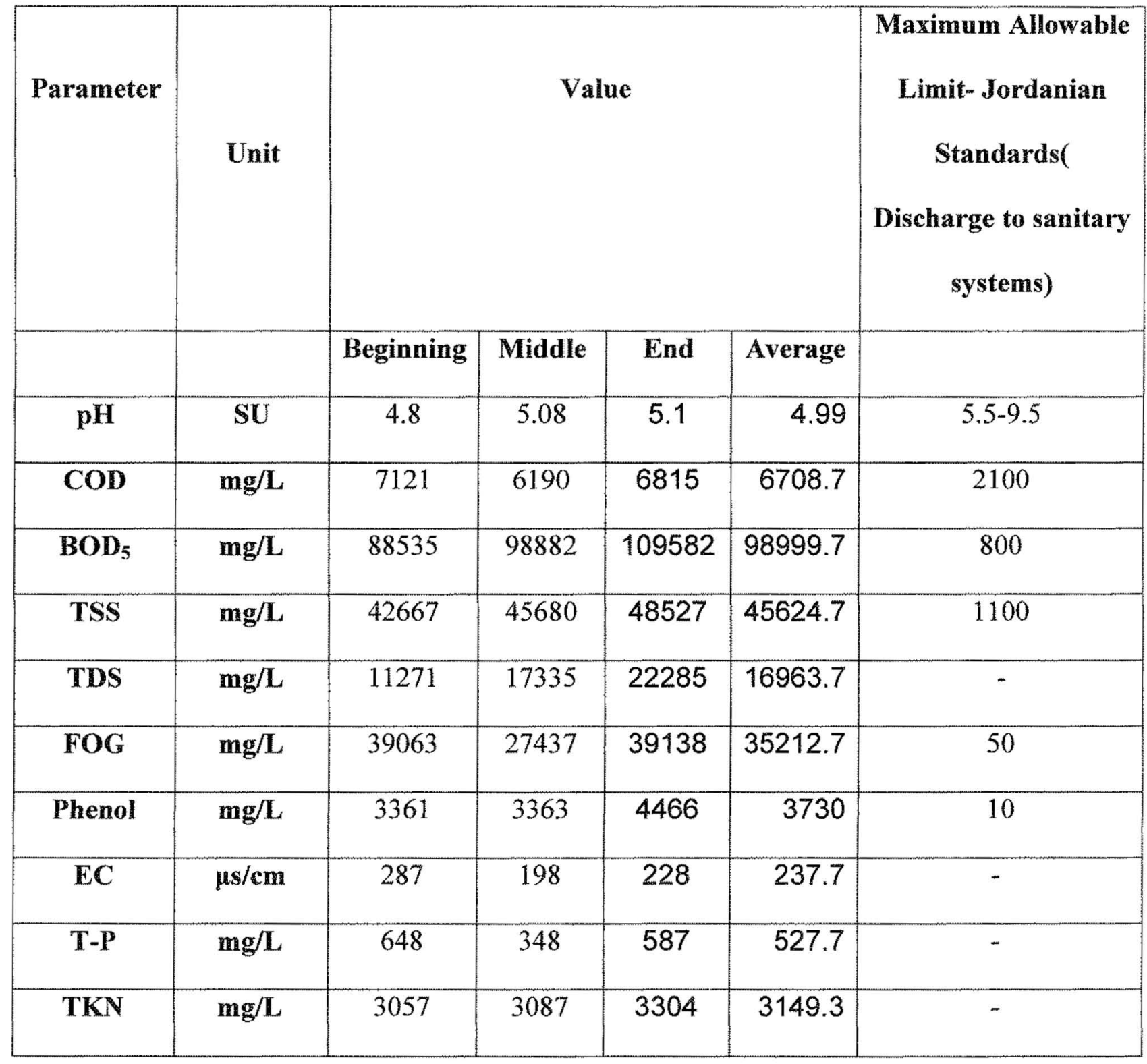




\section{CONCLUSION}

The ongoing stricter policy rules on environmental issues, recent changes in consumer towards the environmental effects of food production, and even stricter regulations voted by the European Union towards reduction of the use of natural resources initiated a great amount of research towards improving the thermal waste treatment methodology. The olive oil industry continues to be one of the most heavily polluting ones among the food industries. Food industry will have to focus on waste avoidance as well as utilization of the process waste. Application of clean technologies greatly enhances the safety and quality of the product as well as reducing the energy requirements and environmental impact of the food industry. The main environmental impacts of the food sector are aquatic, atmospheric and solid waste emissions. Nowadays, the main treatment method of solid wastes is composting, while recovery and reuse of by-products and wastes as raw materials stand for another effective option. Olive-mill wastes are produced by the industry of olive oil production, which is very important economic activity, particularly, for Mediterranean basin countries, leading to a large environmental problem of current concern in this region. This paper presents a current and interesting theme and highlights the environmental concerns associated with olive oil production in Palestine. Although there is no novelty in this field, the results show some interest. The novelty, contribution to the field, technical quality and depth of research are good. The survey conducted reveals that there are local variations in the parameters investigated due to variations in the types of olives. Oil and water content in olives are dependent on location. The olives from the South are found to contain larger solid content than those from either Middle (Center) or North, resulting in lower oil yield and higher solid generation per ton of olive produced. A representative value at $1.7 \mathrm{~m}^{3} /$ ton for wastewater generation is found to be high compared to those values in other places of the world. This requires a technical review of the technology and operation of olive mills in Palestine. The characteristics of OMW are found to violate the standards for OMW and this requires the attention of authorities. This work presents a warning about the impact of OMW in the environment in Palestine.

\section{REFERENCES}

1. C. Paredson, J. Cegarra, A. Roig, M. Sanchez-Monedero and S. Bernal, Bioresource Technology, 67, 111(1999)

2. V. Tamburino, S. Zimbone and P. Quattrone, OLIVAE, 76, 36(1999)

3. S. Hanifi and I Hadrami, J. Agronomy, 7, 63 (2008)

4. B. Kiril, K. Kestioglu and M. Yalili, Ekoloji 17, 39(2008)

5. I.S. Arvanitoyannis, A. Kassaveti and S. Stefanatos, Critical Reviews in Food Science and Nutrition, 47, 187 (2007)

6. I.S. Arvanitoyannis, A. Kassaveti and S. Stefanatos, International J. Food Science and Tech., 42, 852 (2007)

7. I.S. Arvanitoyannis and A. Kassaveti, International J. Food Science and Tech.., 42, 281 (2007)

8. E. Bettazzi, M. Morelli, S. Caffaz, C. Caretti, E. Azzari and C. Lubello, Water Science Tech., 54, 17 (2006) 
9. S. Caffaz, C. Caretti, M. Morelli, C. Lubello and E. Azzari, Water Science and Tech., $55,89(2007)$

10. D. Mantzavinos and N. Kalogerakis, Environ. Int., 31, 289(2005)

11. M. Ugurlu and I. Kula, Environ. Sci. Pollut. Res. Int., 14, 319(2007)

12. J.M. Landete, J.A. Curiel, H. Rodriguez, B. Rivas and R. Munaz, Food Chemistry, $107,320(2008)$

13. S. Hachicha, F. Sellami, J. Cegarra, R. Hachicha, N. Drira, K. Medhioub and E. Ammar, J. Hazard. Mat., 162, 402(2009)

14. Palestinian National Information Center, 2005 (www.pnic.gov.ps)

15. U. Tomati, E. Galli, F. Fiorelli and L. Pasetti, International Biodeterioration and Biodegradation, 38, 155 (1996)

16. Jordanian Ministry of Agriculture. Annual Report, 1998

17. Jordanian Standards No.202 "Industrial Wastewater" (1991) Ministry of Trade and Industry, Department of Specification and Standards

18. Water Authority Law No.18 (1988) Disposal of Industrial and Commercial Wastewater to the Sewer Network, Jordan

19. R. Borja, A. Martin, R. Maestro, J. Alba and J. Fiestas, Process Biochem., 27, 231 (1992)

20. V. Martin, R. Borja, V. Alonso, I. Garcia and C. Banks, Water Research, 28, 489 (1995)

21. M. Hamdi, Applied Biochem. Biotechnol., 37, 155(1992)

22. A. Khatib, F. Aqra, N. Yaghi, Y. Subuh, B. Hayeek, M. Musa, S. Basheer and I. Sabbah, Am. J. Environ. Sci., 5, 1 (2009)

23. J.A. Morillo, B. Antizar-Ladislao, M. Sánchez, R. Cormenzana and N.J. Russell, Applied Microbiology and Biotechnology, 82, 25(2009)

24. Standard Methods for the Examination of Water and Wastewater, American Public Health Association, Edit. 14, 1981 